\title{
Aducanumab, Amyloid Lowering, and Slowing of Alzheimer Disease
}

Stephen Salloway, MD, MS, and Jeffrey Cummings, MD, ScD

Neurology ${ }^{\circledR}$ 2021;97:543-544. doi:10.1212/WNL.0000000000012451

Aducanumab (Aduhelm) was recently approved by the US Food and Drug Administration (FDA) for the treatment of Alzheimer disease (AD). The approval of aducanumab is controversial. We address why we support this decision and welcome the availability of aducanumab as an important therapy for patients with early $\mathrm{AD}$.

Building on a phase $1 \mathrm{~B}$ study that informed dose decisions and demonstrated amyloid lowering by aducanumab, Biogen launched 2 phase 3 trials: EMERGE and ENGAGE. ${ }^{1}$ These were identically designed global trials with 1,600 amyloid-positive participants with early $\mathrm{AD}$ in each trial. At trial initiation, participants were randomized to high dose, low dose, or placebo. A dose increase from $6 \mathrm{mg} / \mathrm{kg}$ to $10 \mathrm{mg} / \mathrm{kg}$ was made for APOE4 gene carriers midway through the trial; EMERGE participants had higher doses for longer periods as the EMERGE trial began later than the ENGAGE trial and patients had more time on the $10 \mathrm{mg} / \mathrm{kg}$ dose. An interim efficacy analysis showed no foreseeable drug-placebo difference, and both trials were stopped. Blinded data continued to accrue and the final data set at week 78 demonstrated that EMERGE met its primary outcome with a $22 \%$ drug-placebo difference in slowing on the Clinical Dementia Rating sum of boxes (CDR-SB) in the high-dose group $(p=0.01)$. Secondary outcomes on standard clinical trial instruments showed significant drug-placebo differences in favor of aducanumab with greater decline in the placebo group than in the aducanumab group in the course of the trial: the $\mathrm{AD}$ Assessment Scale-cognitive subscale showed a 27\% drugplacebo difference $(p=0.009)$, the AD Cooperative Study activities of daily living mild cognitive impairment scale demonstrated a $40 \%$ drug-placebo difference $(p=0.0006)$, and the Mini-Mental State Examination exhibited an $18 \%$ difference $(p=0.04)$. Functional measures are used to determine the clinical meaningfulness of a treatment response ${ }^{2}$; a $40 \%$ reduction in functional decline is statistically significant and clinically important. Amyloid lowering was robust and statistically significant in both dose groups. CSF biomarker analyses revealed significant dose-related reductions in hyperphosphorylated tau in the active treatment groups. Pooled EMERGE and ENGAGE data for tau PET showed increases in the placebo group and less increase or decreases in the high-dose group in several cortical regions. The ENGAGE trial showed no drug-placebo difference for the primary and secondary clinical outcomes in the final data set. There was significant amyloid lowering in both dose arms. Of ENGAGE participants who had completed 14 months of treatment at the $10 \mathrm{mg} / \mathrm{kg}$ dose (the dose recommended in the package insert), there was a $27 \%$ slowing on the CDR-SB comparable to the slowing observed in EMERGE. The principal adverse events occurring in both trials were amyloidrelated imaging abnormalities occurring in 34\% of those in the EMERGE high-dose group and $35.5 \%$ in the ENGAGE high-dose group and leading to $6.6 \%$ and $7.3 \%$ discontinuations in EMERGE and ENGAGE, respectively.

The FDA approved aducanumab using the accelerated approval pathway that allows marketing of a drug based on a biomarker considered reasonably likely to predict clinical benefit. Accelerated approval is accompanied by a requirement to generate additional efficacy and safety data in a postmarketing study. The biomarker considered likely to predict clinical benefit was plaque lowering demonstrated by amyloid PET.

\author{
Correspondence \\ Dr. Salloway \\ ssalloway@butler.org
}

RELATED ARTICLES

Editorial

Clinical Efficacy, Drug

Safety, and Surrogate

Endpoints: Has

Aducanumab Met All of Its Expectations?

Page 517

\section{Viewpoint}

Prescribing Aducanumab in the Face of Meager Efficacy and Real Risks

Page 545 
The body of evidence supporting use of aducanumab in patients with early $\mathrm{AD}$ includes consistent amyloid reduction on PET imaging, slowing of decline on primary and secondary outcome measures in EMERGE, encouraging effects on biomarkers consistent with effect on biological processes linked to disease progression, and preliminary observations of slowing of cognitive decline in other trials of plaque-lowering antibodies (e.g., donanemab ${ }^{3}$ ). The absence of diseasemodifying therapies for $\mathrm{AD}$ supports making the therapy available on the basis of these data. Further study is required to confirm clinical benefits and to identify individuals most likely to respond.

Implementation of aducanumab will make new demands on the health care system, including clinician vigilance for patients with early $\mathrm{AD}$; availability of amyloid PET, lumbar puncture, and MRI resources; and access to infusion centers. We recommend that the patients treated with aducanumab have features similar to those included in the EMERGE/ENGAGE trials: early symptomatic $\mathrm{AD}$ with evidence of brain amyloid. Progress in the development of a blood test for $\mathrm{AD}$ diagnosis would accelerate the integration of aducanumab into the diagnostic/therapeutic workflow. Successful implementation of aducanumab will require collaboration among primary care clinicians and specialists and a commitment to equity of access.

Aducanumab opens a new era in $\mathrm{AD}$ research and care and provides a foundation for development of progressively better therapies.

\section{Study Funding}

The authors report no targeted funding.

\section{Disclosure}

S. Salloway was a site PI and co-chair of the investigator steering committee for the ENGAGE trial and receives research support and consultancy fees from Biogen, Eisai, Lilly, Avid, Genentech, and Roche. J. Cummings has provided consultation to Biogen, Eisai, Acadia, Alkahest, AriBio, Avanir, Axsome, Behren Therapeutics, Cassava, Cerecin, Cerevel, Cortexyme, EIP Pharma, GemVax, Genentech, Green Valley, Grifols, Janssen, Jazz, Karuna, LSP, Merck, Novo Nordisk, Otsuka, ReMYND, Resverlogix, Roche, Signant Health, Sunovion, Suven, United Neuroscience, and Unlearn AI pharmaceutical and assessment companies; owns the copyright of the Neuropsychiatric Inventory; and has the following research support: NIGMS P20GM109025, NINDS U01NS093334, NIA R01AG053798, NIA P20AG068053, NIA R35AG71476. Go to Neurology.org/ $\mathrm{N}$ for full disclosures.

\section{Publication History}

Received by Neurology June 15, 2021. Accepted in final form June 23, 2021.

\begin{tabular}{lll} 
Appendix & Authors \\
\hline Name & Location & Contribution \\
\hline $\begin{array}{l}\text { Stephen } \\
\text { Salloway, } \\
\text { MD, MS }\end{array}$ & $\begin{array}{l}\text { Butler Hospital and Warren } \\
\text { Alpert Medical School of } \\
\text { Brown University, } \\
\text { Providence, RI }\end{array}$ & $\begin{array}{l}\text { Drafting/revision of the } \\
\text { manuscript for content, } \\
\text { including medical writing for } \\
\text { content }\end{array}$ \\
\hline $\begin{array}{l}\text { Jeffrey } \\
\text { Cummings, } \\
\text { MD, ScD }\end{array}$ & $\begin{array}{l}\text { Chambers-Grundy Center for } \\
\text { Transformative } \\
\text { Neuroscience, Department of } \\
\text { Brain Health, School of } \\
\text { Integrated Health Sciences, } \\
\text { University of Nevada Las } \\
\text { Vegas }\end{array}$ & $\begin{array}{l}\text { Dranuscript for content, } \\
\text { including medical writing for } \\
\text { content }\end{array}$ \\
& & \\
\hline
\end{tabular}

\section{References}

1. US Food and Drug Administration. Combined FDA and applicant PCNS Drugs Advisory Committee briefing document. Accessed July 4, 2021. https://www.fda. gov/media/143502/download.

2. Leber P. Guidelines for the clinical evaluation of antidementia drugs. Food and Drug Administration; 1990.

3. Mintun MA, Lo AC, Duggan Evans C, et al. Donanemab in early Alzheimer's disease. N Engl J Med. 2021;384(18):1691-1704.

\section{Neurology $y^{\circledast}$ Online CME Program}

Earn CME while reading Neurology. This program is available only to online Neurology subscribers. Read the articles marked CME, go to Neurology.org, and click on CME. This will provide all of the information necessary to get started. The American Academy of Neurology (AAN) is accredited by the Accreditation Council for Continuing Medical Education (ACCME) to sponsor continuing medical education for physicians. Neurology is planned and produced in accordance with the ACCME Essentials. For more information, contact AAN Member Services at 800-879-1960. 


\section{Neurology}

\section{Aducanumab, Amyloid Lowering, and Slowing of Alzheimer Disease Stephen Salloway and Jeffrey Cummings \\ Neurology 2021;97;543-544 Published Online before print July 7, 2021 \\ DOI 10.1212/WNL.0000000000012451}

\section{This information is current as of July 7, 2021}

\section{Updated Information \& Services}

\section{References}

Citations

Subspecialty Collections

Permissions \& Licensing

Reprints including high resolution figures, can be found at: http://n.neurology.org/content/97/11/543.full

This article cites 1 articles, 0 of which you can access for free at: http://n.neurology.org/content/97/11/543.full\#ref-list-1

This article has been cited by 3 HighWire-hosted articles: http://n.neurology.org/content/97/11/543.full\#\#otherarticles

This article, along with others on similar topics, appears in the following collection(s):

\section{All Cognitive Disorders/Dementia}

http://n.neurology.org/cgi/collection/all_cognitive_disorders_dementia Alzheimer's disease

http://n.neurology.org/cgi/collection/alzheimers_disease

MCI (mild cognitive impairment)

http://n.neurology.org/cgi/collection/mci_mild_cognitive_impairment

Information about reproducing this article in parts (figures,tables) or in its entirety can be found online at:

http://www.neurology.org/about/about_the_journal\#permissions

Information about ordering reprints can be found online:

http://n.neurology.org/subscribers/advertise

Neurology ${ }^{\circledR}$ is the official journal of the American Academy of Neurology. Published continuously since 1951, it is now a weekly with 48 issues per year. Copyright (O) 2021 American Academy of Neurology. All rights reserved. Print ISSN: 0028-3878. Online ISSN: 1526-632X.

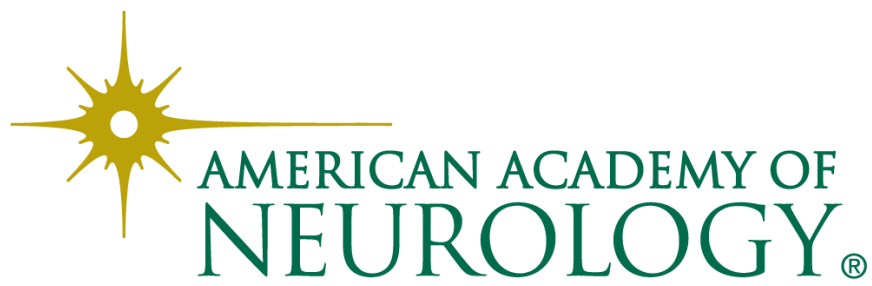

